\title{
Disruption of the actin cytoskeleton in budding yeast results in formation of an aberrant cell wall
}

\author{
Miroslav Gabriel and Marie Kopecká
}

Author for correspondence: Miroslav Gabriel. Tel: +42542126 261. Fax: +42542126200.

Department of Biology, Faculty of Medicine, Masaryk University, 66243 Brno, Joštova 10, Czech Republic

\begin{abstract}
A temperature-sensitive, conditionally lethal actin mutant of Saccharomyces cerevisiae, DBY 1693, was used to study, using light and electron microscopy, dysfunction of the actin cytoskeleton in the morphogenesis of the cell wall. Cells of this mutant strain survived at least $24 \mathrm{~h}$ at the restrictive temperature $\left(37^{\circ} \mathrm{C}\right)$. These cells showed isodiametric growth. Mutant cells accumulated vesicles, probably as a consequence of chaotic secretory transport caused by loss of polarity. A conspicuous morphological response to the dysfunction of actin was the formation of an aberrant wall over the whole surface of the isodiametrically-growing cell. This wall was of loose texture with protruding glucan microfibrils incompletely masked with amorphous matrix. It resembled the regenerating cell wall on the surfaces of yeast protoplasts. The localization of wall synthesis over the whole surface of temperature sensitive actin mutant cells was in accordance with an even distribution of submembranous actin in the form of patches (similarly to regenerating protoplasts). Delocalization of finger-like invaginations of the plasma membrane from the bud region to the whole surface of the growing cell was also found in mutant cells.
\end{abstract}

Keywords: temperature-sensitive actin mutant, Saccharomyces cerevisiae, aberrant wall synthesis, cortical actin cytoskeleton

\section{INTRODUCTION}

Studies of the dynamics of the actin cytoskeleton during the cell cycle in budding yeasts have indicated the importance of actin for polarized growth of the cell surface (Kilmartin \& Adams, 1984; Adams \& Pringle, 1984; Barnes et al., 1990). The vital role of actin in yeasts was first demonstrated in lethal mutants (Shortle $e t$ al., 1982) with the use of a constructed mutated actin allele from ACT1 (Gallwitz \& Seidel, 1980; Gallwitz \& Sures, 1980; $\mathrm{Ng} \&$ Abelson, 1980).

Further studies of the pleiotropic effect of the mutant actin gene have been facilitated by the construction of temperature-sensitive, conditionally lethal yeast mutants (Shortle et al., 1984). At a permissive temperature of $23^{\circ} \mathrm{C}$, the substitution mutation in the actin gene is manifested by a prolonged cell generation time and by the absence of actin cables; the mutant cells are, however, viable and able to reproduce by mitotic cell cycle (Novick

Abbreviations: DAPI, 4,5-diamino-2-phenylindole; EF, exoplasmic fracture; ts, temperature sensitive.
\& Botstein, 1985). At a restrictive temperature of $37^{\circ} \mathrm{C}$, asymmetric distribution of actin patches was lost within $60 \mathrm{~min}$, chitin in cell walls was delocalized, secretory vesicles accumulated in the cell, secretion of periplasmic proteins was partially inhibited, cells gradually assumed rounded shapes and, during budding, became osmotically fragile and died within $4 \mathrm{~h}$ (Novick \& Botstein, 1985). Spherical mutant cells showed actin evenly distributed as patches under the whole cell surface.

We have found that a low proportion of temperature sensitive (ts) actin mutant cells of Saccharomyces cerevisiae DBY 1693 survived 1 or $2 \mathrm{~d}$ under the restrictive conditions. However, they had lost cell polarity and only grew isodiametrically. These surviving cells became models for a study of manifestations of actin dysfunction in cell wall morphogenesis which is described in this paper.

\section{METHODS}

Yeast strain. The strain used was Saccharomyces cerevisiae DBY 1693, genotype $M A T \mathrm{Ta} / M A T \alpha$, ura 3-52/+, bis 4-619/+, with actin allele act $1-1 / \operatorname{act} 1-1$, from a collection of ts yeast actin 
mutants (Novick \& Botstein, 1985) which was kindly provided by Professor David Botstein and Dr P. Grisafi of the Massachusetts Institute of Technology, Cambridge, USA.

Media. YEPD medium was used, comprising $1 \%(\mathrm{w} / \mathrm{v})$ yeast extract, $2 \%(\mathrm{w} / \mathrm{v})$ bactopeptone and $2 \%(\mathrm{w} / \mathrm{v})$ glucose (Novick \& Botstein, 1985). Solid media contained 2.5\% (w/v) agar.

Growth of strains. Cell cultures were prepared by inoculation of liquid medium with stationary-phase cells followed by $24 \mathrm{~h}$ incubation with agitation at $23^{\circ} \mathrm{C}$. Temperature shift to $37{ }^{\circ} \mathrm{C}$ was made when exponentially-growing cells had attained a density of about $10^{6}$ cells $\mathrm{ml}^{-1}$. They were then cultivated at $37^{\circ} \mathrm{C}$ for $24 \mathrm{~h}$ before being used for experiments.

Immunofluorescence staining of yeast cells. Immunofluorescence procedures used were based on the methods of Pringle et al. (1989). The cells were fixed in YEPD medium supplemented with $20 \mathrm{mM} \mathrm{MgCl}$ and $10 \mathrm{mM} \mathrm{EGTA}$ at room temperature for $90 \mathrm{~min}$. Before visualization the specimens were washed three times with phosphate buffer at $\mathrm{pH} 6.9$.

Actin visualization. Actin was labelled with rhodamine phalloidin R-415 (Molecular Probes Inc.). After staining for 30-60 min, specimens were washed five times with phosphate buffered saline and placed on grease-free slides. The slides were mounted in $p$-phenylenediamine in $90 \%(\mathrm{v} / \mathrm{v})$ glycerol, $\mathrm{pH} 9 \cdot 0$. All phases of staining were performed under red light.

Microtubule visualization. Cells were first processed with $20 \%$ (w/v) snail enzyme (isolated and purified crude digestive juice of Helix pomatia, prepared in our laboratory and dried at $0^{\circ} \mathrm{C}$ ) and phosphate buffer ( $\mathrm{pH} \mathrm{6.9)}$ for $20 \mathrm{~min}$ at room temperature to digest cell walls. The cells were subsequently washed with phosphate-buffered saline (PBS) and applied to a cover slip. After drying for $60 \mathrm{~min}$, cells were permeabilized by methanol for $10 \mathrm{~min}$ and by acetone for $1 \mathrm{~min}$ in a refrigerator. The samples were preincubated in PBS containing $2 \%(\mathrm{v} / \mathrm{v})$ bovine serum albumin (PBS-BSA) for $20 \mathrm{~min}$ at $37^{\circ} \mathrm{C}$ and then incubated with primary anti-tubulin antibody TU 01 for $60 \mathrm{~min}$ at $37^{\circ} \mathrm{C}$. After washing with PBS, secondary antibody SwAMFITC was applied for $45 \mathrm{~min}$ at $37^{\circ} \mathrm{C}$ (Hašek et al., 1986). After three washes with PBS, samples were viewed in a mounting medium.

Nuclear staining. This was performed by adding $1 \mu \mathrm{g} 4,5-$ diamino-2-phenylindole (DAPI) $\mathrm{ml}^{-1}$ (Sigma) to the mounting medium.

Cell wall staining. Cells were stained using calcofluor white $\left(25 \mu \mathrm{ml}^{-1}\right.$ from a stock solution in PBS of $\left.1 \mathrm{mg} \mathrm{ml}^{-1}\right)$, which bound non-specifically to the microfibrillar system of the cell wall (Streiblová, 1984).

Freeze-etching. Replicas were prepared using living cells. After cultivation, the cells were placed onto copper discs, frozen in Freon 22 and liquid nitrogen. Replicas were prepared after sublimation for $1 \mathrm{~min}$ at $-100^{\circ} \mathrm{C}$ in a Balzers apparatus (BA 360) by the method of Moor \& Mühlethaler (1963).

Ultrathin sections. Cells were fixed in $2 \%(\mathrm{v} / \mathrm{v})$ glutaraldehyde for $2 \mathrm{~h}$ at room temperature, postfixed with $1 \%$ (w/v) $\mathrm{OsO}_{4}$ for $1 \mathrm{~h}$ and embedded in Durcupan ACM. Sections were prepared with a Reichert Ultracut $E$ ultramicrotome and stained with uranyl acetate and lead.

Electron micrographs. Specimens were viewed and photographed in a Tesla BS 500 electron microscope.

Light microscopy. Observations were made using (i) phase- contrast microscopy (Amplival, Zeiss-Jena), (ii) Nomarski differential interference contrast microscopy, and (iii) fluorescence microscopy (Jenalumar, Zeiss-Jena, Germany).

\section{RESULTS}

\section{Growth, nuclear division, the cytoskeleton and cell wall of large spherical actin mutant cells}

Cells of the ts actin mutant, when transferred from the permissive $\left(23{ }^{\circ} \mathrm{C}\right)$ to restrictive $\left(37^{\circ} \mathrm{C}\right)$ temperature, changed their shape from ellipsoidal (Fig. 1a) to spherical in $3 \mathrm{~h}$ and died within 12-24 h. Death was often due to the lysis of cell walls, which most frequently occurred at the apex of medium-sized buds in budding cells (data not shown). We observed very small buds either separated, as tiny balls, from the mother cells or attached, aberrantly, to the wall of growing mother cells. Cells with large buds produced rounded pairs. These cells, as well as nonbudding cells, eventually died usually without wall lysis, although death from wall lysis was also observed.

A certain proportion of cells survived the critical period at the restrictive temperature. These cells increased their volume by isodiametric growth. After $24 \mathrm{~h}$ of cultivation at the restrictive temperature, the culture contained, apart from dead cells, $4-10 \%$ of large, spherical cells which exceeded the initial cells in volume by about 100-fold (Fig. 1b). If maintained at the restrictive temperature, the large cells eventually died. However, if after $24 \mathrm{~h}$ cultivation at the restrictive temperature, these cells were transferred back to the permissive temperature, some of them were able to revert back to budding cells and start a new population which, initially, was very heterogeneous.

The large spherical cells of the ts actin mutant that developed at the restrictive temperature were multinuclear, with in most cases between 4 and 16 nuclei (Fig. 2). Disorders in nuclear division were evident from the second cycle of nuclear division, as manifested by three nuclei in some cells; the number of nuclei in one cell was not always a multiple of the previous number, even though the microtubular cytoskeleton was preserved and relatively extended. In spherical cells, cytoplasmic microtubules followed an arch-like path (Fig. 3).

Actin in the large, spherical cells growing at the restrictive temperature was present in patches under the plasma membrane distributed evenly all over the cell (Fig. 4a, b). This was in contrast with cells grown at the permissive temperature and wild-type cells, in which actin patches were localized asymmetrically, mainly in the bud neck and at the bud apex (Gabriel et al., 1992).

Most of the large, isodiametrically-growing cells showed, after staining with calcofluor, a distinct layer of new cell wall under the remnant of old, non-growing wall when viewed by fluorescence microscopy (Fig. 5a). The wall produced at the restrictive temperature often appeared, under a cap of the old wall formed at the permissive temperature, to be thicker than the wall opposite (Fig. $5 b)$. 

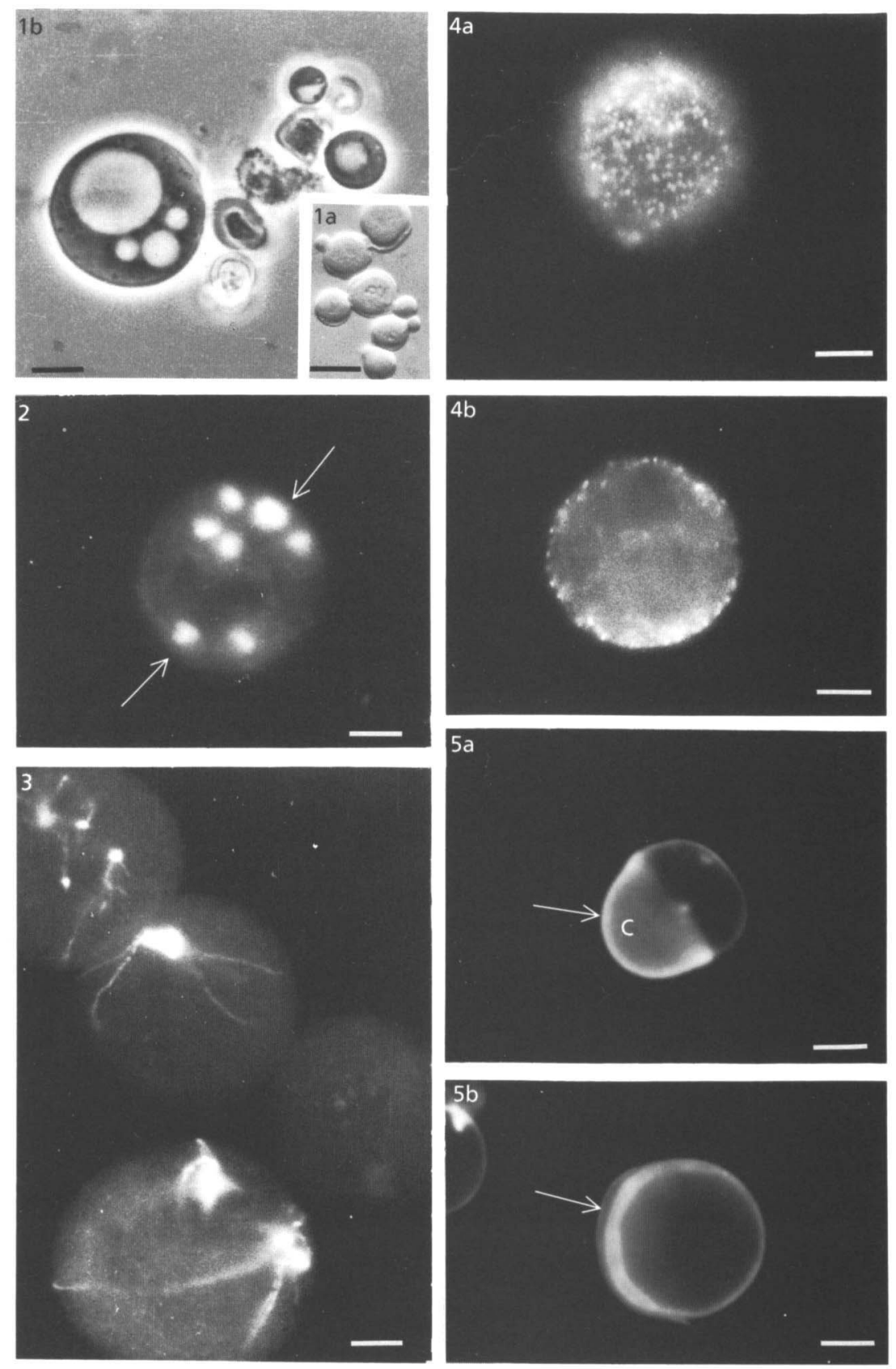

Fig. 1. Cells of ts actin mutant DBY 1693. (a) Cells growing at a permissive temperature of $23^{\circ} \mathrm{C}$. Differential interference contrast microscopy. Bar, $10 \mu \mathrm{m}$. (b) A large spherical cell surviving at the restrictive temperature for $24 \mathrm{~h}$ surrounded by dead cells. Phase-contrast microscopy. Bar, $10 \mu \mathrm{m}$.

Fig. 2. Nuclear division in isodiametrically-growing cells of the ts actin mutant surviving at the restrictive temperature. Seven nuclei are visible (arrows). Stained with DAPI. Bar, $10 \mu \mathrm{m}$.

Fig. 3. The microtubular apparatus is preserved in ts actin mutant cells. It seems more pronounced in large spherical cells. Incubated with TU 01. Bar, $10 \mu \mathrm{m}$.

Fig. 4. Actin patches evenly distributed under the whole surface of isodiametrically-growing cells of ts actin mutant subjected to the restrictive temperature. Two planes of focus, upper (a) and central (b), demonstrate the submembranous localization of actin patches. Actin labelled with rhodamine-phalloidin. Bar, $10 \mu \mathrm{m}$.

Fig. 5. After transfer of ts actin mutant cells to the restrictive temperature, new wall synthesis begins on the whole surface of isodiametrically-growing cells. They show 'caps' of the original wall formed at the permissive temperature (arrow) $(a, b)$. The aberrant nature of the new wall is evidenced by its varying thickness (b). Stained with calcofluor white. Bar, $10 \mu \mathrm{m}$. 

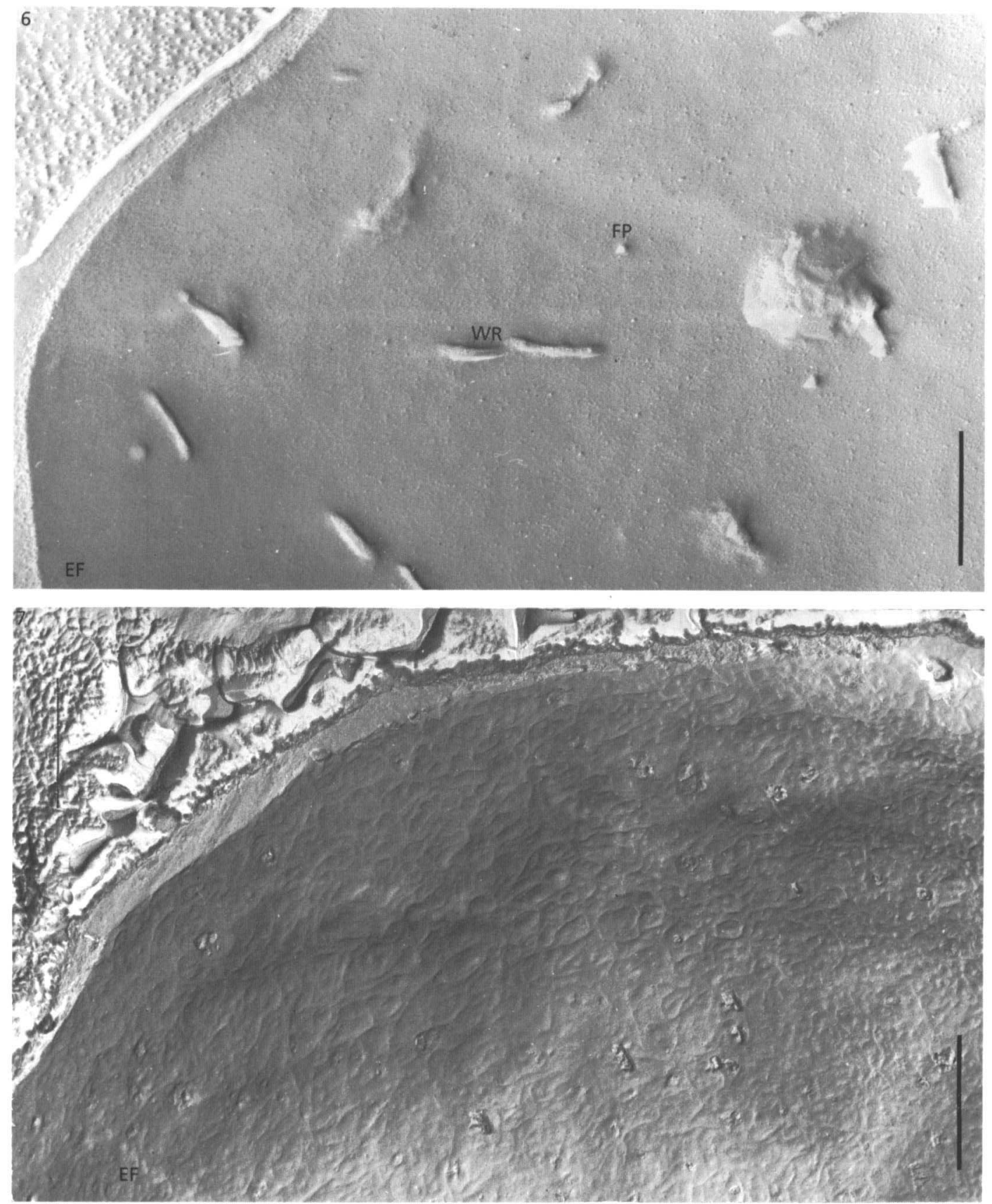

Fig. 6. Electron micrograph of the exoplasmic fracture (EF) face of the plasma membrane (terminology according to Branton et al., 1975) showing the impression of the inner surface of the cell wall in the wild yeast strain DBY 1690. The wall is comparatively homogeneous on cross-fracture, its inner surface is smooth with occasional wall ridges (WR) and finger-like protrusions (FP). Freeze-etching. Bar, $1 \mu \mathrm{m}$.

Fig. 7. Electron micrograph of the EF face of the plasma membrane showing the impression of the inner surface of the wall in the ts actin mutant DBY 1693 grown at the restrictive temperature. Glucan fibrils protrude above the inner surface and are incompletely masked with amorphous matrix. Freeze-etching. Bar, $1 \mu \mathrm{m}$.

\section{Ultrastructure of cell walls of ts actin mutants}

The cell walls of both the control strain DBY 1690 (Fig. 6 ) and the ts actin mutant strain growing at the permissive temperature had smooth inner surfaces with occasional ridges. The thickness of the wall was about $0.3 \mu \mathrm{m}$; the texture of the wall in cross-section was masked with amorphous matrix.

In the large, spherical ts mutant cells, the inner wall surface showed a distinct network of glucan microfibrils (Fig. 7). The amorphous matrix, which did not cover the 

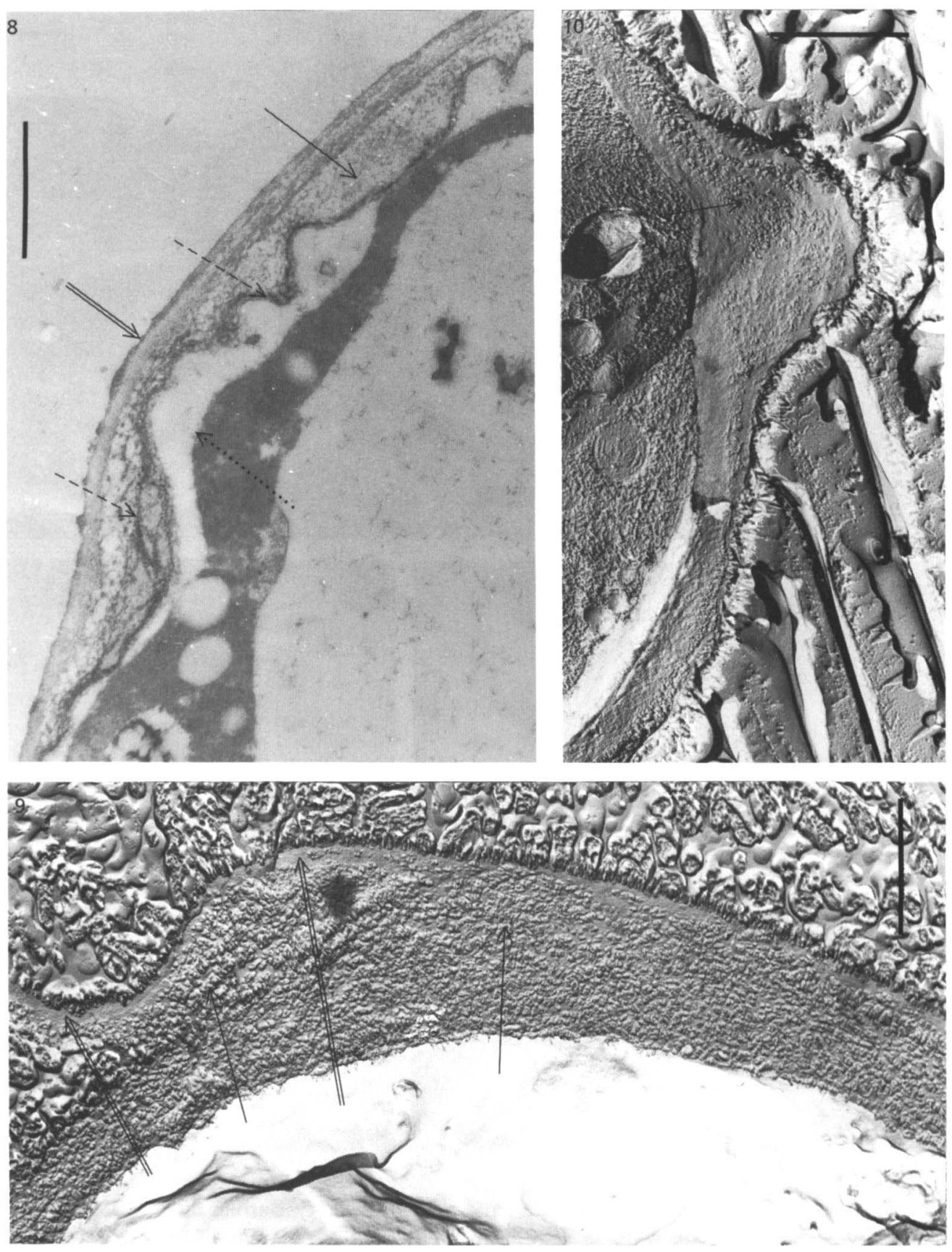

Fig. 8. Electron micrograph of an ultrathin section through a part of the ts actin mutant cell growing isodiametrically at the restrictive temperature. Under a homogeneous layer of old wall developed at permissive temperature (double arrow) there is an irregular, loose layer of new aberrant cell wall synthesized at the restrictive temperature (arrow). Sections through microfibrils are discernible. The innermost, thin, dense layer of the cell wall is, in some areas, seen as a loose microfibrillar component (dashed arrows). The plasma membrane (dotted arrow) is separated from the cell wall artificially. Ultrathin section. Bar, $1 \mu \mathrm{m}$.

Fig. 9. Electron micrograph of a oblique section through the cell wall of a ts actin mutant cell grown at the restrictive temperature (arrows). The thickness of this aberrant wall is evident as well as the coarse texture of its fracture. The old cell wall (double arrow) attached to the outer side of the new wall is becoming detached. Freeze-etching. Bar, $1 \mu \mathrm{m}$.

Fig. 10. Electron micrograph of a ts actin mutant cell fractured in the region where a small bud emerged (arrow) at the permissive temperature. At the restrictive temperature, the bud was masked with matrix material of the newly developing aberrant cell wall. Freeze-etching. Bar, $1 \mu \mathrm{m}$. 

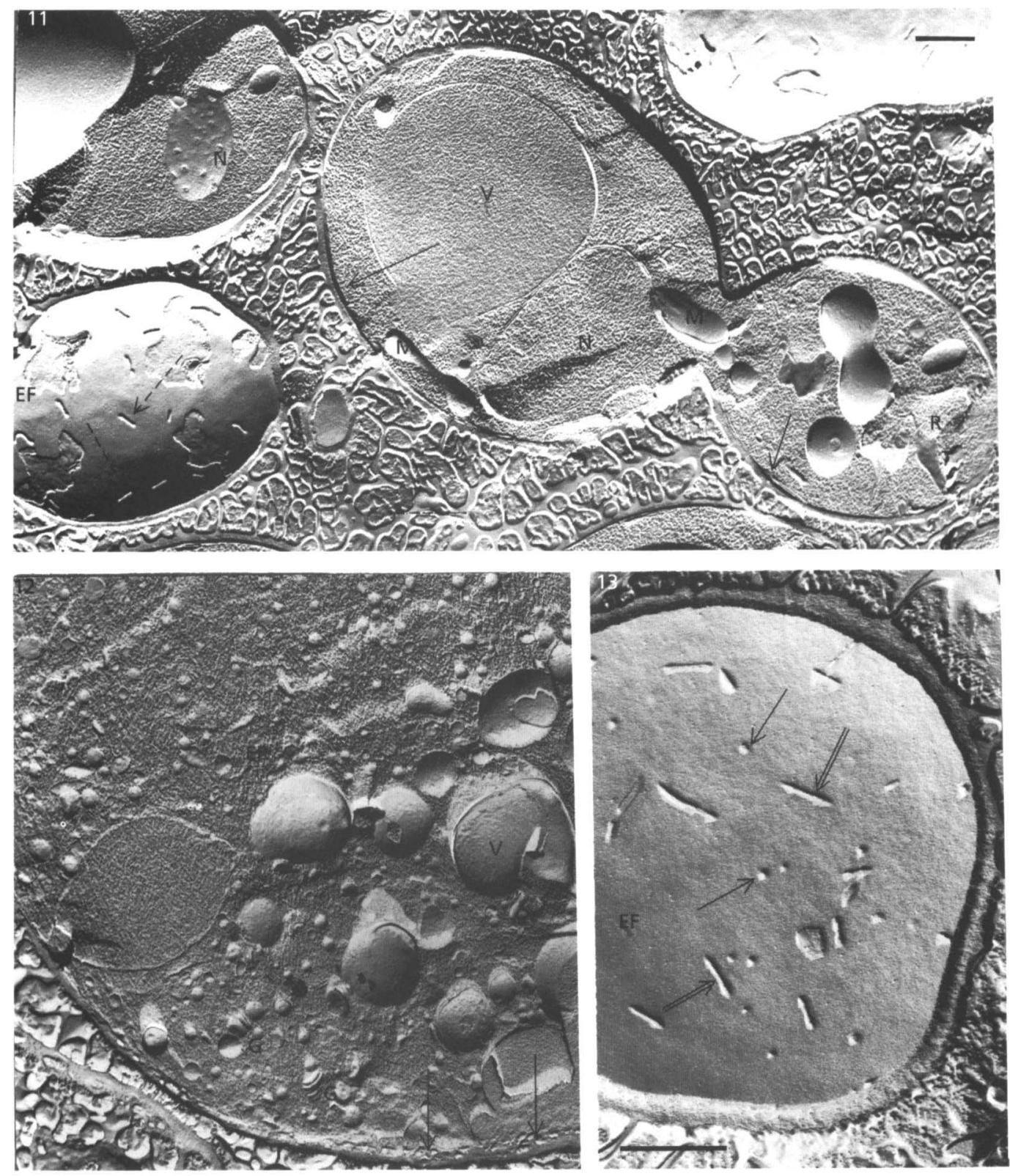

Fig. 11. Electron micrograph of a fracture through a budding yeast of wild-type strain DBY 1690. Vacuole (V), nucleus $(\mathrm{N})$, mitochondria (M), endoplasmic reticulum (R). Vesicular structures in the cytoplasm are infrequent and the cell wall is of even thickness (arrows). In a different cell, the EF face of the plasma membrane reveals the inner surface of the cell wall with ridges (dashed arrows). Freeze-etching. Bar, $1 \mu \mathrm{m}$.

Fig. 12. Electron micrograph of a fracture through a ts actin mutant cell grown at the restrictive temperature for $2 \mathrm{~h}$. The cytoplasm contains large numbers of minute vesicles $(v)$ and vacuoles $(V)$ varying in size, endoplasmic reticulum (ER) and Golgi apparatus (G). Vesical structures are occasionally accumulated under the plasma membrane (arrows). Freezeetching. Bar, $1 \mu \mathrm{m}$.

Fig. 13. Electron micrograph of the EF face of the plasma membrane revealing an impression of the inner surface of the cell wall in ts actin mutant cells growing at the restrictive temperature. Wall ridges (double arrows) and evenly distributed finger-like protrusions of cell wall material (arrows) are typical of apical growth in budding cells. Freezeetching. Bar, $1 \mu \mathrm{m}$.

fibrillar component completely, protruded through large meshes above the inner surface. A similar observation was made on the outer surface of a new aberrant wall, particularly in the areas where the old wall was removed by fracturing. The outer irregularities and, particularly, the inner surfaces of the aberrant wall were clearly seen in ultrathin sections (Fig. 8). Walls produced at the restrictive temperature varied in thickness and their texture was 'loose' in contrast with the homogeneous appearance of old walls. The thickness of the aberrant walls formed at 
the restrictive temperature exceeded, in some cases, that of the old wall about 10-fold (Fig. 9). The cell wall aberrations were even more distinct in cells surviving for $24 \mathrm{~h}$ or more at the restrictive temperature. Walls of the cells growing at the restrictive temperature for only $1-2 \mathrm{~h}$ did not show any marked aberrations. In cells which started budding before transfer to the restrictive conditions, the rudiments of buds were filled with amorphous wall material (Fig. 10).

\section{Ultrastructure of ts actin mutant cells surviving at the restrictive temperature}

Examination of the ultrastructure of actin mutant cells transferred from permissive to restrictive conditions and surviving the lethal time limit $(12-24 \mathrm{~h})$ revealed accumulation of components of the secretory pathway, i.e. endoplasmic reticulum, Golgi complex and numerous vesicles, but also vacuoles, in the cytoplasm when compared with the control, non-mutated cells (Figs 11 and 12). These findings varied between cells of the same population. No distinct aberrations were observed in endoplasmic reticulum membranes, nuclear membranes or in the plasma membrane. Vesicles situated close to the plasma membrane were observed infrequently (Fig. 12). The wall ridges typical of normal cells were seen only occasionally, but finger-like protrusions of the cell wall were spread all over the inner surface of the cell wall of isodiametrically-growing actin mutant cells (Fig. 13). In control cells, these structures were observed on the inner surface of the wall of bud apices.

\section{DISCUSSION}

\section{Disruption of actin cables results in a loss of polarity and subsequent isodiametric growth of cells}

In wild-type budding yeast cells, actin cables run predominantly parallel to the long axis of cell growth (Drubin et al., 1988). Although the role of actin in the cellular transport mechanism is still not clear (Goldstein \& Vale, 1992) the prevailing opinion is that fungal actin microfilament cables are involved in polar transport of vesicles of the exocytosis pathway (Johnston et al., 1991; Harold, 1991) and, consequently, also in the mechanism of polar growth of cells.

In most instances, photomicrography did not detect long actin cables in the ts actin mutant DBY 1693; these results are similar to the findings of Novick \& Botstein (1985). Nevertheless, we assume that the filamentous form of actin was present and functional in cells incubated at the permissive temperature and dysfunctional at the restrictive temperature. This was demonstrated by Drubin $e t$ al. (1993) in the yeast actin mutant act 1-129. Yeast cells with dysfunctional actin microfilaments due to mutation in the actin gene ceased to grow in a polar fashion and assumed a spherical shape (Novick \& Botstein, 1985). Our results demonstrated that some ts actin mutant cells could survive for some time and continue growing isodiametrically at the restrictive temperature.

Enlarged spherical shapes have been reported in cells mutated in the genes responsible for actin-associated proteins, such as the actin-associated $85 \mathrm{kDa}$ protein (Drubin et al., 1988; Johnston et al., 1991), and $65 \mathrm{kDa}$ protein (Adams et al., 1989), tropomyosin (Liu \& Bretscher, 1989), profiline (Haarer et al., 1990) and capping proteins (Amatruda et al., 1990). These aberrant spherical yeast morphologies may all be ascribed to the same mechanism - dysfunction of actin microfilaments.

Rounded phenotypes have also been reported in mutants carrying mutation in 'bud site assembly genes' (Drubin, 1991). These genes are necessary for the development of cell polarity in the morphogenetic pathway involved in bud formation; their protein products may serve as targets for actin-associated proteins related to the assembly of actin microfilaments before bud formation.

Rounded phenotypes have been described in cells in which the disruption of actin microfilaments occurs due to external factors acting on the phenotype, for instance, in hypertonic media (Chowdhury et al., 1992) or during protoplasting achieved by removal of the cell wall by snail enzymes in the presence of osmotic stabilizer (Kobori et al., 1989). As long as regenerating protoplasts maintained their spherical shape produced by protoplasting, actin microfilaments were not detected (Kobori et al., 1989; Jochová et al., 1991; Gabriel et al., 1992). However, if polar growth, i.e. budding, was resumed in regenerated protoplasts, the resulting revertants again contained actin cables (Gabriel et al., 1992).

\section{F-actin patches and cell wall synthesis in yeast}

F-actin patches were found in budding yeasts co-localized with regions of the future chitin ring in the cell wall and with growing zones of the bud wall (Kilmartin \& Adams, 1984; Adams \& Pringle, 1984). This coincidence in actin patches and chitin localization in ts actin mutants (Novick $\&$ Botstein, 1985) indicated that actin patches were related to chitin synthesis.

In normal cells, actin patches are accumulated in the bud and its neck. In isodiametrically-growing cells, they are evenly distributed below the plasma membrane, under the whole surface on which new (aberrant) cell wall is synthesized. Their localization in close relation to the areas of wall synthesis is evident. Similar observations were made in regenerating spherical protoplasts of $S$. cerevisiae in which actin patches were also evenly distributed under the surface of protoplasts constructing new cell walls. After the cell wall had been completed and the cytoskeleton restored, relocation of actin patches and their accumulation in the region of the bud and the newly developing septum occurred (Gabriel et al., 1992). This timing of localization of actin patches with sites of active wall synthesis provides evidence of the involvement of actin patches in the synthesis of wall components. Delocalization of actin patches associated with the change of polar into isodiametric growth suggests that mutation in the yeast actin gene does not interrupt the function of the cortical form of F-actin.

The present views on the relation of actin patches to chitin synthesis (Kilmartin \& Adams, 1984; Adams \& Pringle, 
1984; Novick \& Botstein, 1985) are based on colocalization of actin patches with regions of cell wall stained with calcofluor. However, the specificity of reaction between calcofluor and chitin is questionable (Pringle et al., 1989). The nature of actin patches and their function can be understood only with the use of detailed and specific methods. Using colloidal gold, F-actin has recently been detected under the plasma membrane and its co-localization with finger-like plasma membrane invaginations has been related to endocytosis (Mulholland et al., 1994). We suggest that these structures could be associated with an exogenous rather than endogenous process, being sites of wall component (microfibril) synthesis. The first and main components synthesized in de novo regeneration of the cell wall in yeast protoplasts are glucan microfibrils (Kreger \& Kopecká, 1976; Nečas \& Svoboda, 1985). Thus, the reasons for chitin to be considered to be the component whose synthesis is related to actin patches are questionable.

\section{Aberrant wall in ts actin mutant cells}

The isodiametrically-growing cell of the ts actin mutant surviving for some time at the restrictive temperature produces an aberrant wall varying in thickness in different parts of its surface. The wall consists mostly of microfibrils. The fibrillar component in budding yeasts is built of $(1 \rightarrow 3)$ - $\beta$-glucan (Kopecká et al., 1974; Fleet, 1991; Klis, 1994). The mutant fibrillar network is loose with large meshes and with microfibrillar bundles protruding above the exoplasmic fracture (EF) face of the plasma membrane. This architecture suggests incomplete formation of the fibrillar component of the cell wall. However, the most conspicuous feature of this aberrant cell wall is a deficiency of the amorphous component.

The finger-like structures of the EF face of the plasma membrane caused by protrusions of the cell wall, in budding yeasts are found predominantly on bud apices, while in actin mutants at restrictive temperature, they are distributed over the whole EF surface. It can be speculated whether these structures could be related to the finger-like invaginations described by Mulholland et al. (1994).

The failure to detect actin cables in ts actin mutant cells incubated at the restrictive temperature and the accumulation of transport vesicles in their cytoplasm indicate that, in the absence of a functioning actin cytoskeleton, isodiametric growth is induced and maintained by means of a disorganized system of intracellular transport. One consequence of this is impaired exocytosis of wall material. This gives rise to loose, unevenly thick and incomplete aberrant wall covering the whole surface of an isodiametrically-growing cell. Added to it are remnants of the compact wall formed previously under the permissive temperature.

\section{Concluding remarks}

The most important findings of this study were that, as a consequence of the dysfunctional actin cytoskeleton (actin microfilaments), the polar transport of secretory vesicles to the bud disappeared, the distribution of wall material was disoriented but occurred mostly, in an even pattern, under the whole surface of actin mutant cells growing isodiametrically at the restrictive temperature, the new aberrant cell wall was synthesized around the whole cell surface, and the delocalization of cell wall synthesis coincides with the delocalization of actin patches.

\section{ACKNOWLEDGEMENTS}

This work was supported by a grant from the Grant Agency of the Czech Republic, no. 204/93/0667.

\section{REFERENCES}

Adams, A. E. M. \& Pringle, J. R. (1984). Relationship of actin and tubulin distribution to bud growth in wild-type and morphogenetic mutant Saccharomyces. J Cell Biol 98, 934-945.

Adams, A. E. M., Botstein, D. \& Drubin, D. G. (1989). A yeastactin-binding protein is encoded by $S A C 6$, a gene found by suppression of an actin mutation. Science 243, 231-233.

Amatruda, J. F., Vannon, J. F., Tachell, K., Hug, C. H. \& Cooper, J. A. (1990). Disruption of the actin cytoskeleton in yeast capping protein mutants. Nature 344, 352-354.

Barnes, G., Drubin, D. G. \& Stearns, T. (1990). The cytoskeleton of Saccharomyces cerevisiae. Curr Opinion Cell Biol 2, 109-115.

Branton, D., Bullivant, S., Gilula, N. B., Karnovsky, M. J., Moor, H., Múhlethaler, K., Northcote, D. H., Packer, L., Satir, B., Satir, P., Speth, V., Staehelin, L. A., Steere, R. I. \& Weinstein, R. S. (1975). Freeze-etching nomenclature. Science 190, 54-56.

Chowdhury, S., Smith, K. W. \& Gustin, M. C. (1992). Osmotic stress and the yeast cytoskeleton: phenotype-specific suppression of an actin mutation. J Cell Biol 118, 561-571.

Drubin, D. (1991). Development of cell polarity in budding yeast. Cell 65, 1093-1096.

Drubin, D., Miller, K. G. \& Botstein, D. (1988). Yeast actin-binding proteins: evidence for a role in morphogenesis. J Cell Biol 107, 2551-2561.

Drubin, D. G., Heather, D. J. \& Wertmen, K. F. (1993). Actin structure and function: roles in mitochondrial organization and morphogenesis in budding yeast and identification of the phalloidin-binding site. Mol Cell Biol 4, 1277-1294.

Fleet, G. H. (1991). Cell walls. In The Yeasts, vol. 4, pp. 199-279. Edited by A. H. Rose \& J. S. Harrison. London: Academic Press.

Gabriel, M., Kopecká, M. \& Svoboda, A. (1992). Structural rearrangement of the actin cytoskeleton in regenerating protoplasts of budding yeasts. J Gen Microbiol 138, 2229-2234.

Gallwitz, D. \& Seidel, R. (1980). Molecular cloning of the actin gene from yeast Saccharomyces cerevisiae. Nucleic Acids Res 8, 1043-1059.

Gallwitz, D. \& Sures, I. (1980). Structure of a split gene: complete nucleotide sequence of the actin gene in Saccharomyces cerevisiae. Proc Natl Acad Sci US A 77, 2546-2550.

Goldstein, L. S. B. \& Vale, R. D. (1992). New cytoskeletal liaisons. Nature 359, 193-194.

Haarer, B. K., Lillie, S. H., Adams, A. E. M., Magdolen, V., Brandlow, W. \& Brown, S. S. (1990). Purification of profilin from Saccharomyces cerevisiae and analysis of profilin-deficient cells. J Cell Biol 110, 105-114.

Harold, F. M. (1991). Biochemical topology : from vectorial metabolism to morphogenesis. Biosci Rep 11, 347-385. 
Haక̌ek, J., Svobodová, J. \& Streiblová, E. (1986). Immunofluorescence of the microtubular skeleton in growing and drugtreated yeast protoplasts. Eur J Cell Biol 41, 150-156.

Jochová, J., Rupeš, I. \& Streiblová, E. (1991). F-actin contractile ring in protoplasts of the yeast Scbizosaccharomyces. Cell Biol Int Rep 15, 607-610

Johnston, G. C., Prendergast, J. A. \& Singer, B. A. (1991). The Saccharomyces cerevisiae MYO 2 gene encodes an essential myosin for vectorial transport of vesicles. J Cell Biol 113, 539-551.

Kilmartin, J. V. \& Adams, A. E. M. (1984). Structural rearrangement of tubulin and actin during the cell cycle of the yeast Saccbaromyces. $J$ Cell Biol 98, 922-933.

Klis, F. M. (1994). Review: cell wall assembly in yeast. Yeast 10, 851-869.

Kobori, H., Yamada, N., Taki, A. \& Osumi, M. (1989). Actin is associated with the formation of the cell wall in reverting protoplasts of the fission yeast Schizosaccharomyces pombe. J Cell $S_{c i}$ 94, 635-646.

Kopecká, M., Phaff, H. J. \& Fleet, G. H. (1974). Demonstration of a fibrillar component in the cell wall of the yeast Saccharomyces cerevisiae and its chemical nature. $J$ Cell Biol 62, 66-76.

Kreger, D. R. \& Kopecká, M. (1976). On the nature and formation of the fibrillar nets produced by protoplasts of Saccharomyces cerevisiae in liquid media: an electron microscopic, $\mathrm{X}$-ray diffraction and chemical study. J Gen Microbiol 92, 207-221.

Liu, H. \& Bretscher, A. (1989). Disruption of the single tropomyosin gene in yeasts results in the disappearance of actin cables from the cytoskeleton. Cell 57, 233-242.
Moor, H. \& Mahlethaler, K. (1963). Fine structure in frozen-etched yeast cells. J Cell Biol 17, 609-628.

Mulholland, J., Preuss, D., Moon, A., Wong, A., Drubin, D. \& Botstein, D. (1994). Ultrastructure of the yeast actin cytoskeleton and its association with the plasma membrane. J Cell Biol 125, 381-391.

Nełas, O. \& Svoboda, A. (1985). Cell wall regeneration and protoplast reversion. In Fungal Protoplasts, pp. 115-133. Edited by J. F. Peberdy \& L. Ferenczy. New York: Marcel Dekker.

$\mathbf{N g}$, R. \& Abelson, J. (1980). Isolation of the gene for actin in Saccharomyces cerevisiae. Proc Natl Acad Sci US A 77, 3912-3916.

Novick, P. \& Botstein, D. (1985). Phenotypic analysis of temperature-sensitive yeast actin mutants. Cell 40, 405-416.

Pringle, J. R., Preston, R. A., Adams, A. E. M., Stearns, T., Drubin, D. G., Haarer, B. K. \& Jones, W. E. (1989). Fluorescence microscopy methods for yeasts. Methods in Cell Biology 31, 357-435.

Shortle, D., Haber, J. \& Botstein, D. (1982). Lethal disruption of the yeast actin gene by integrative DNA transformation. Science 217, 371-373.

Shortle, D., Novick, P. \& Botstein, D. (1984). Construction and genetic characterization of temperature-sensitive alleles of the yeast actin gene. Proc Natl Acad Sci USA 81, 4889-4893.

Streiblová, E. (1984). The yeast cell wall. A marker system for cell cycle controls. In The Microbial Cell Cycle, pp. 117-142. Edited by P. Nurse \& E. Streiblová. Boca Raton, FL: CRC Press.

Received 19 August 1994; revised 7 December 1994; accepted 9 January 1995. 